\title{
Behavioral Finance as An Alternative Concept in Investor- Related Risk for Residential Projects : A Literature Review
}

\author{
Aditya Sutantio ${ }^{1}$, I Putu Artama Wiguna ${ }^{2}$ \\ Postgraduate Program, Civil Engineering \\ Institut Teknologi Sepuluh Nopember (ITS) \\ Jalan Arief Rahman Hakim, Surabaya 60111 Indonesia \\ email : aditya.wbm@gmail.com, artama@ce.its.ac.id
}

\begin{abstract}
Stakeholder is a very important factor for project success. As part of external and the most influential project stakeholder, investor as a market agent, with embedded needs, preferences and behavior might become critical project risks and should be identified and managed properly as a key project objective. This paper investigates previous studies to examine and to understand the mechanisms of investor's economic behavior as the risk factor and its impact for the development of residential project. Traditional financial theory in the past decades generally emphasizes the rational model in investor's decision-making without involving emotional aspect of behavior. Recently there are many scientists proposed the theory of behavioral finance which combines insight from psychology and sociology into finance and investment with the market fundamental perspective. Based on the review, we conclude that behavioral finance can be considered as an alternative concept in assessing residential project risk especially in economic volatility.
\end{abstract}

Keywords - Investor's behavior, behavioral finance, risk analysis, residential project.

\section{INTRODUCTION}

The Project Management Body Of Knowledge (PMBOK) [1] described project risk as an uncertain event or condition that, if it occurs, has a positive or negative effect on one or more project objectives. Known risks are those that have been identified and analyzed, making it possible to plan responses for those risks. Known risks that cannot be managed proactively, should be assigned a contingency reserve. Unknown risks can not be managed proactively and therefore may be assigned a management reserve. A risk may have one or more causes and, if it occurs, it may have one or more impacts. A cause may be a given or potential requirement, assumption, constraint, or condition that creates the possibility of negative or positive outcomes. If either of these uncertain events occurs, there may be an impact on the project goals. Risk conditions may include aspects of the project's or organization's environment that contribute to project risk, such as immature project management practices, lack of integrated management systems, concurrent multiple projects, or dependency on external participants who are outside the project's direct control. Focusing in property investment, Adair and Hutchison [2] describes risk as "the probability that a target rate of return will not be realized". In order to simplify the risk analysis, they can be classified into internal and external risks. Risks which are out of the project's control should be taken into account because they are potential factors of adverse effects in the direction of project and the goals achievement of the project, primarily in economic and financial target [3]. As part of the external risk potential is the project stakeholders who are impacted by or can impact the project in a positive or negative way [4]. It is critical to identify the stakeholders early and to analyze their levels of interest, their expectations and their importance and influence that might risk the project success. Project stakeholders are individuals, groups, or organizations who may affect, be affected by, or perceive themselves to be affected by a decision, activity, or outcome of a project [1]. One of the external most influential stakeholder as a source of project economic risk are the investors or buyers. Their expectations, preferences and economic behavior are of enormous importance and should be analysed as project economic and financial risk source. In order to fill the gap in the existing literature provide different perspective and tools to be adopted in risk assessment of property investment for real estate practitioners [5], in this paper we review investor related economic risks. Risks associated with economic and financial uncertainties are in fact the most crucial factors that might have strong impacts on residential project development and its overall goals.

The increasing recognition that investor as one of the most important stakeholder and asset of any organization and that they must be treated as the organization's top priority as they are the ones who pay the costs and the survival of any organization depends on them [6] so it could become a critical risk factor of project, has actuated many residential developers to focus on their investors and involve them in the product development process. Understanding the investor's need, preference and expectation as well as behavior are essential because risks that has its origin in the behavior of the investors are mostly uncontrollable external risks resulting in market instability such as boom and bust phenomenon that might cause serious impacts on project targets, especially in economic goals [7].

In order to obtain a deeper understanding in evaluating residential project risk so the managers and relating participants could manage the risk in an appropriate manner, we focus on highlighting the economic risks for 
development of residential project based on the household investor's behavior perspective, since household investor is the dominant player in housing market. This paper begins by introducing a concept of investor's behavior and behavioral finance as project risk; it then outlining economic risks in project development; and discussing the impact of investor behavior on residential project risk.

\section{CONCEPT OF INVESTOR'S BEHAVIOR}

The decision of purchasing residential property may be one of the most important transaction people will ever make because for most of investors, houses are the most valuable assets and important component of household wealth, and the emotional attachment when houses become homes is inevitable [8] [9]. Psychology of an investor basically deals with three strands of psychology : (1) rational or cognitive behavioral psychology, (2) emotional and preferences and (3) social psychology. These three strands effect investor behavior and decision during the investment process. The rational or cognitive behavioral psychology describe the mental state thinking and learning of investor; how they calculate the value of investment based on investment or economic fundamentals while making decision. Emotional responses deals with psychology on how wisely an investor apply his/ her emotions while making decision. Preferences relate to the attributes of products that are evaluated by the investor to meet their needs and satisfaction, while social psychology relates to investor's consideration on the society's welfare encouragement [10]. We concentrate and limit the review of the literatures on the concept of rationality and psychological behavioral of the investor that causes project economic risk.

\subsection{Rational behavior.}

Residential or housing can be treated as both investment and consumption. A majority of studies focused on the investment function of property and the role of valuation process [11]. Investment decisions in residential real estate are traditionally assumed to be a rational process. The process concentrates on sets of rules that the decision makers should follow [12]. Conventional financial theory is based on the notion that investors act rationally, correctly considering all currently available information in the decision making process [13]. Such "decision makers" are characterised as logically weighing up the respective benefits and costs before deciding. This is popular as the concept of "utility maximisation". Utility maximisation is a theory based on the assumption of rational decision making. Utility maximisation at the individual level refers to the Efficient Market Hypothesis, as introduced by Fama [14]. Efficient Market Hypothesis states that markets provide all available information for investor decision making. Applied to residential project, this way of thinking implies that future house prices, values and growth, which in fact unpredictable, are based on currently available information. In residential project, the heterogenous nature of houses in terms of size, condition, orientation, design, location, attachment, price, etc., make this a challenging condition. Moreover, these markets need to hold in all states of nature (i.e. all risks can be offset).

Although it is commonly recognised that property markets are rather illiquid, the majority of academics and practitioners assume that these markets are efficient, and that the agents make decision in accordance with rationality and normative process. Farlow [15] argues that the fundamental determinants of housing price in this efficient market are income, interest rate, housing stock, demographic change, credit availability and the tax structure. This normative process can be devided into different stages. Jaffee and Sirmans [16] proposed a model to structure residential project investment decisions. This model consists of five stages including analysis of the initial environment, setting goals, analysis on market conditions and a combination of technical and financial consideration. According to Vriend [17], rationality in economics, specifically in property investment decision means that an individual agent chooses (one of) the most advantageous options, given his preferences, in his perceived opportunity set. Opportunities are defined such that all perceived costs and benefits are taken into account; in particular, information, decision making and transaction costs. These subjective perceptions are sometimes called "beliefs" or "expectations". Investor is an agent with given preferences, pursuing his self-interest, seeking to do the best he can get his opportunities. As perceived opportunity sets will never be empty, each agent will always in all circumstances be able to choose a most preferred decision. Thus, what is really fundamental in economic theory including property investment are preferences. This economic theory basically refers to neoclassical economic perspective on how individuals interact have dominated the academic history of the field and how it has influenced investment decision maker [18]. Classical and neoclassical economics have taken into consideration and analysed only economic and objective factors in decision making. Although they knew that not only objective factors are decisive, classical and economical researcher have not given importance to psychological factors in the decision-making process, this way creating the normative models in decision-making. Interested in the mathematics of the alternative route that brings the greatest profit as a refrection of self-interest, they have sought to develop formal procedures which can calculate the optimum decision. The main normative pattern is that the rationality of the subject decider. It assumed that, in making its decision, the human subjects behave rationally, considering merely on the several attributes of houses in terms of size, condition, orientation, design, location, attachment, price and then seeking to choose the optimum alternative, that option which assures maximum payoff of all possible alternatives.

The best known rational and regular models calculate expected value and expected utility as follows [19]:

(1). Expected value.

Expected value is the benefit-calculated, which the investor has in mind in terms of the selection of an alternative. Expected value is a numeric expression and a characteristic of objectivity in the sense that is 
independent of subjective perception of individuals involved in decision process.

\section{(2). Expected utility.}

The expected utility model aims to overcome the restrictions which the expected value calculation struggle, trying to formalise the decision of activity in which the related gain an option does not have a numerical expression. It starts from the idea that there is a difference between value and utility; the value is a given objective, while the utility is subjective perception of value.

The expected or maximum utility model is determined based on the premise that, in calculating the optimum alternative, the investor consider the usefulness, not the value of each alternative. To give a mathematical expression, this utility is coded by a serial number. This number has a relative significance corelation with the size of complimentary utilities. With all this complexity, the expected utility has a psychological validity more than expected value model.

It is more likely because it assumes that the choice between the alternatives is determined by its utility, not their value, so the subjective is the reflection of the value. In some situation the investor's behavior is in line with this model. Payne et al [20] vary the complexity of decisions that some decision makers have sufficient time and information for choosing and deciding an alternative out of many options. It reveals that, in a sufficient time and complexity reduced decision, they behave rationally, doing the calculation in maximising utility. However, in a situation where time is limited or when the complexity of decision making exists, the investor used various heuristic and simplified models.

To summarize the review, in every property investment situation there exist rational behavior and choices.

\subsection{Behavioral finance.}

Over the past decades, studies on the investor related to residential project risks generally based on rational behavior. This is in line with he concept of utility maximisation which leads to the efficient market hypothesis which states that efficient market provide all information regarding risks and opportunities in housing market. Efficient market means that market knows best. It means that if there would be a crises and other financial risks to the market, it would resolve itself by the market because market always know that what should do in this situation. In the mid of 2009, financial market started to leap up and down with wild abandon for several years. Residential market and financial risks become apparent when the price and sales plunge to violent fluctuation. According to standard economic theory, market value should be a reflection of companies' long term economic prospects in terms of sales and growth, refer to the economic fundamentals, and these cannot possibly change so quickly. There must be something else happening here [21].

Recently, there are many studies and findings reveal that the investors' decision is not influenced only by rational and technical fundamentals, but also by emotional or attitude which relate to the uniqueness of the project environment that provide limited and imperfect information relating to the macroeconomics and global situation. These factors can result in biased outcome on project success measurement [13]. By the end of the 1980s, many studies concluded that housing markets are inefficient. Case and Schiller [22] find that information relating to interest rate, which should be an important determinant, does not appear to be incorporated into the pricing of residential project. Farlow [15] stated that the plausible explanation for dramatic increase in houses price and value during the last decades cannot be found in supply and demand fundamentals. Therefore, to a large extend, residential value and growth are determined by the behavior of investors and financial institution. De Bondt [23] finds that, as well as economic fundamentals, institutional factors such as taxes and regulation play a role, but institutional factors alone cannot explain residential market volatility. Farlow[15] explains that the rapid increase in house price and value of the project during the early 2000s stating that a large portion of investors were dissilutioned by equities and moved their assets to the housing market.

In short, the studies found that residential market is, to certain extend, inefficient. One of the most critics of rationalist models was Herbert Simon. He noted that classical theory is a theory of why a man choosing between alternative fix and known, each being attached consequences also known. When however, between the decision-maker and the environment goal, there is perception and other cognitive processes, these models cease to be adequate [24].

As a reaction to rational behavior model that demonstrates market inefficiency and the absence of the influence of human and social behavior, an alternative approach to project risks emerged. This approach is called behavioral economics and its derivate named behavioral finance. It deviates from the traditional neoclassical financial risk model in treating property risks not just from the perspective of financial and physical characteristics of the house, but extending its to the investor emotional behavior. It combines insights from psychology and sociology into property finance and investment. Gallimore at al [12] hypothesised that individual decision making exhibit cognitive limitation biases. A number of biases have been found in residential valuation processes. We discuss the source of investor behavior biases and its impact on residential project development.

\section{(1). Information availability.}

Market imperfections concerning the availability of information can make investors deviate from the normative process. It can also result in mistaking the most recent price changes as representative bias.

\section{(2). Over-optimism.}

Farlow [25] argues that over-optimism is the most visible psychological bias in residential market. He shows that household believe that buying a house does not involve a great deal of risk and house prices will increase more than usual. They also exhibit over optimism in asessing the future interest rate and other fundamentals.

(3). Over confidence and irrational probability evaluation. Over confidence is a bias resulted from a mental 
illusion of control, in regards to an underestimation of risk. Over confidence can also originate from hindsight bias where people think thay knew certain events in advance so it gives people the impression of making unpredictable events as predictable.

\section{(4). Herd behavior and irrational exuberance.}

According to the acceptance of residential market, the herding behavior of investors can be defined as the tendency of investor to imitate the actions of other market participants, thus ignoring their own information and belief [26]. This concept is located on the border between classical and behavioral finance. It is shown to be a source of mispricing and speculative bubbles [27]. Morone et al. [28] showed an individual making a decision is likely to override the private information they hold. Herd behavior has important consequences. It is the cause of irrational exuberance, where market reach "high and unsustainable level under the influence of market psychology" [27]. Overvaluation of assets can occur because of self amplifying reactions of investors to deviation from the equilibrium [29]. Bikhchandani et al[30] classify herd behavior into two categories: intentional herding behavior and false herding behavior. The former refers to the clear intention of the investors to imitate the behavior of other participants. On the other hand, the false herding behavior is based on the situation when a group of investors have the same difficulties in taking an investment decision.

\section{(5). Regret theory.}

Another psychological bias which makes households deviate from rational behavior is regret theory. It implies that people anticitpate on the regret of making a bad investment decision. In practice, people are motivated to invest in residential market because they see other people receiving high return on their investment. Instead of acknowledging the increased risk of capital losses, they participate in the market because they want to avoid having regret about not investing.

\section{(6). Loss aversion.}

Loss aversion is another phenomenon that makes household investment in residential biases. This is where home owners are affected by reference points such as purchace price, and are unable to cope selling their house at a loss. In other words, investors tend to be too willing to sell high return assets but too unwilling to sell lossmaking asset; investors are risk aversion when in profit, risk loving when in loss [31].

\section{(7). Anchoring.}

Anchoring is the most described source of biased asset valuation. Achoring causes valuations to be biased towards an initial starting estimate. The anchors used by appraiser and individual are: the uncomplete contract price of a comparable property; the uncomplete contract price of the subject property, and the value opinions of others.

Although there are valuables for prescriptive purposes, normative models are not adequate when the purpose is for descriptive theories that explain how people actually develop decisions [32]. In his theory of decision-making
Herbert Simon noted that classical theory is a theory of why a man choosing between alternative fixed and known, with a known consequences [24]. When there is perception and other cognitive processes between the investor and the environment goal, these models are not sufficient. In this sense, Simon has created model of bounded rationality, a basic concept in behavioral economic, which is based on the fact that individuals are limited to the level of information to which they may have access in their minds of cognitive limitations and limited period of time that they are available to make a decision. Simon showed that both decision maker ability and its risks will be examined with the same level of objectivity and the same analytical system, but with taking the fact of limited information and theoretical skills of the investor into consideration.

Bounded rationality views that decision is in a heterogenous medium/ society where people have different desires dan preferences, and this must be taken into account when the investor has to investment. Investors, constrained by their own cognitive and ability and time limit, will not necessarily choose the most optimal alternative. Instead, they will take the satisfactory alternative. An alternative is considered satisfactory or otherwise with regard to several relevant criteria. Since they do not have sufficient cognitive information that meets the criteria and/or time to make an inventory of all alternatives and compare their value, utility and risk, the investment choice is likely not the best alternative. In many cases, the individual is under pressure to take decision quickly, he uses minimal number of criteria. This ways of thinking is called heuristic, meaning that decision making is not based on the rules of optimization, but rather on speculative method, trials, erroneous and permissive rules.

To describe the rationality concept, we cited the map proposed by Backman et al. [33]. It shows two components of rationality: (1) "Demons" and (2) Bounded rationality. Term "demons" implies that the individual investor is a rational actor with unlimited rationality and optimization constraint, while the bounded rationality is limited to satisfaction and heuristics (figure 1). The term "heuristic" means that people use simple "rule-ofthumbs", often unconsciously in order to make investment decision when there is a lot of information involved, much uncertainty, and a realistic time constraint. Kahneman et al [32] supported the result by similar pattern stating that there are two forms of decision making: reasoning and intuition. Reasoning is a deliberate process (slow, serial, controlled, effortful, rule-governed) while intuition tends to happen spontaneously without specific efforts which reflects fast, parallel, automatic, reflects fast, parallel, automatic, effortless, emotional and associative processes.

Many empirical studies of investment decision process shows that investor does not conform to the classical restricted theory of rational choice, because every time has tendency to simplify the available choice, to ignore some of the information or to make decisions guided by more than instict after the model optimalisation. Through the review, it is obvious that in the concept of behavioral finance as a descriptive model, it is necessary to pay attention and to examine the cognitive, emotional and 
subjective factors comprehensively in making investment decisions as well as the financial fundamentals to reveal the more wholistic risks factor of residential project.
When the market capitalization rate is higher than the asset's capitalization rate, the investment riskiness is moderate or aggresive. On the other hand, if the market

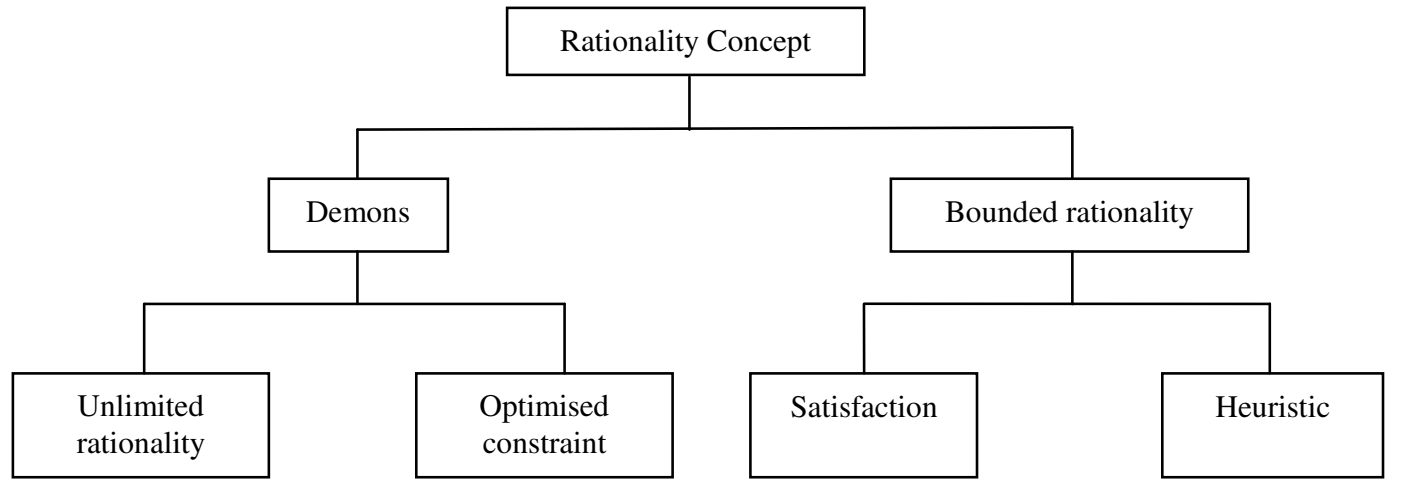

Figure 1 . The concept of rationality [33]

\section{ECONOMIC RISKS IN RESIDENTIAL PROJECT}

There are several parameters which explain economical risks with respect to investor behavior residential project. In this paper we take two significant risks and the risk analysis approach.

\subsection{Market risk and real estate Operating risk.}

Table 1.

Risk Classification

\begin{tabular}{cll}
\hline \multirow{2}{*}{ Classification } & \multicolumn{2}{c}{ Risk Classification } \\
\hline \multirow{2}{*}{ Market Risks } & $\mathrm{CMr}$ & Capital Market risk \\
\cline { 2 - 3 } & $\mathrm{Vr}$ & Valuation risk \\
\cline { 2 - 3 } & $\mathrm{MGRr}$ & Market Growth Rate risk \\
\hline \multirow{3}{*}{ Real Estate } & $\mathrm{Or}$ & Operating risk \\
\cline { 2 - 3 } Operating Risks & $\mathrm{Dr}$ & Development risk \\
\cline { 2 - 3 } & $\mathrm{Lr}$ & Leasing risk \\
\cline { 2 - 3 } & $\mathrm{LHr}$ & Leasehold risk \\
\cline { 2 - 3 } & $\mathrm{LVr}$ & Leverage risk \\
\cline { 2 - 2 } & $\mathrm{Tr}$ & Tax risk \\
\hline
\end{tabular}

Chen and Khumpaisal [34] classify economic risks in residential development projects as shown in Table 1.

We mainly address Market Risks rather than Operating Risks as the former is more intuitive and are strongly related to the investor's behavior and are affected by external factors such as financial markets as well as macroeconomics condition.

Market risks can be sub-classified into three categories: Capital Market risk (CMr); Valuation risk (Vr) and Market Growth risk (MGRr). We review to some details.

\section{(1). Capital Market risk (CMr)}

Capital Market risk is the riskiness of the asset which relates to market capitalization rate and its value reveals whether the asset is priced consistently with capital market prices and rates. It is calculated as the ratio between the average market capitalization rate (MCR) and the asset's capitalization rate (ACR):

$C M r=\frac{M C R}{A C R}$ asset's capitalization rate, the investment riskiness is moderate or aggresive. On the other hand, if the market capitalization rate is lower than the project's capitalization (2). Valuation risk (Vr)

Valuation risk reflects whether an asset is overvalued and will earn less than expected when it matures or is sold in the second market. Factors influencing to $\mathrm{Vr}$ include incomplete or biased data, market volatile and poor data analysis performed by the professional assessing the asset value. Overvalued assets might generate losses for the investors as well as the developers. The value of real estate assets can be generally grouped into two categories: cash flow from contracts (or from the primary market) and resale price. Cash from contracts is more certain and has less risk, while the resale price is more uncertain. In fact, the greater the reliance on the resale activities to result in the desired return, the greater the risk of the asset.

With respect to the resale price, Valuation risk is determined as follows:

$V r=\frac{N P V R P}{A P}$

where NPVRP is the Net Present Value (NPV) of residual (or resale) and AP is the asset's construction/ acquisition cost. If the value of $\mathrm{Vr}<20 \%$, the investment risk can be considered as conservative; when $20 \%<\mathrm{Vr}<60 \%$ the investment is moderate; and when the $\mathrm{Vr}$ value $>60 \%$, it means that the risk is aggresive.

\section{(3). Market Growth Rate risk (MGRr)}

Market Growth Rate risk defines the probability that the asset value increases overtime. This risk calculation is used to compare the project value growth rate to the overall market growth rate. If the asset growth rate surpasses inflation rate, the value increase is depending on factors such as capturing below market rent, overheated sales or rental growth expectation. It is necessary to measure the asset growth rate and compare it to the 
similar property market growth or inflation rate for the purpose to determine whether the asset is being acquired above market growth rates. The MGRr is calculated using the following formula:

$M G R r=\frac{U I R R-A C R}{M G R}$

where UIRR is the unlevered rate of return, ACR is the initial asset capitalization rate and MGR is the overall market griwth rate. The value if MGRr represents the property investment's growth rate. When MGRr is > $125 \%$, the risk is considered as aggresive, $75 \%$ $<$ MGRr $<125 \%$, the investment's risk is moderate and it is conservative when the value is $<75 \%$.

The relative value range for each investment risk components is classified based on conservative, moderate or aggresive class, as shown in Table 2 . The classification ranges is determined based on residential property investor's judgments and real estate experts for certain property market.

Table 2.

Classification of Risks Value Range

\begin{tabular}{cccc}
\hline \multirow{3}{*}{ Risk } & \multicolumn{3}{c}{ Riskiness Value Range } \\
\cline { 2 - 4 } & Conservative & Moderate & Aggresive \\
\hline $\mathrm{CMr}$ & $<90 \%$ & $90-110 \%$ & $>110 \%$ \\
\hline $\mathrm{Vr}$ & $<20 \%$ & $20-60 \%$ & $>60 \%$ \\
\hline $\mathrm{MGRr}$ & $<75 \%$ & $75-125 \%$ & $>125 \%$ \\
\hline
\end{tabular}

We should take careful attention in interpreting the risk value. Although the overall investment riskiness can be considered fairly moderate, in the case of financial instability, the investor will decide not to proceed and to delay the decision to invest when one or more critical risks value are in the aggresive range, because he considered the risk factor is unacceptable according to his risk attitude. Therefore, the developer should be wise and well experienced in setting project strategies to avoid capital risk, valuation risk and market growth rate risk factor related to investor behavior.

\subsection{Bubble formation risk.}

In many of the world's fastest growing economies there is a strong process of urbanization, with strong growth in households' disposable income and an increasing demand for new homes. This has led to rising real estate prices and increasing production volumes [35]. Considering the real estate sector strong influence on the economy, this development is a powerful engine in overall economic growth. But this development also poses a threat if it leads to a so called bubble formation. If the reason that the [asset] price is high today is only because investors believe that the selling price will be high tomorrow when "fundamental" factors do not seem to justify such a price - then a bubble exists' [24]. It occurs when housing prices rose dramatically and then fell, leaving the average price exceeds the fundamental value [36]. Such deviation is possible as houses are assets and hence some buyers might be willing to pay a higher price for houses than is fundamentally justified as they believe in further price increases. In many countries, assets bubble is commonly acknowledged as the most potential cause of economic, financial, and in particular, residential market turbulence.
Hence this phenomenon is a high risk factor that should be taken into consideration by real estate developers as be as investors.

There are many indicators in assessing residential risk analysis that tend to affect the market volatility and bubble formation. We present some of the indicators commonly used by researchers and practitioners.

\section{(1). Housing prices vs. vacancy rate.}

A large number of vacancies will have a pressure on prices, since in this case; supply exceeds demand [37].

\section{(2). Price rent ratio.}

When the ratio between the price of a property and the market rent increase far above the historical average, a bubble can be suspected [7]. But if the relation between price and supply can be assumed to be permanently inelastic, or if rents are below market rents, a price increase above the historical average can be supported by fundamentals. The value of commercial property can be derived from the income it is expected to generate, i.e. the net operating income (NOI) minus capital expenditure (capex). If the real estate value increases faster than the income it produces the yield is falling, making the investment questionable.

\section{(3). Real housing prices vs. supply elasticity.}

If demand increases, but supply does not, prices can be expected to go up.

(4). Housing price vs. disposable income.

When the owner's net income, minus ownership costs (disposable income), decreases due to increasing cost for ownership, like increasing interest rates, this indicates a risk that prices will decrease, since the owners' capacity to pay is reduced.

\section{(5). Housing prices vs. building costs.}

Assuming that productivity increases at the same rate in the building industry, as it does in the rest of the economy, and all other influencing factors are help constant, real property prices ought to decline as a function of increased productivity. [35].

(6). The loan to value ratio (LTV).

It is a good indicator for the risk involved for the lender as well as for the borrower. The higher the ratio the higher is the risk.

\section{(7). The debt service coverage ratio (DSCR).}

DSCR is the ratio of funds available for the payment of interest and principal. This is, also, considered a good indicator for the level of risk involved.

\section{(8). The ratio between loan and disposable income.}

This ratio should not change over time. An increase above the long term average indicates that the market may be overvalued.

\section{(9). Housing prices vs. interest rates.}

If interest rate increases it will be more costly to own a piece of real estate and to compensate for the higher user cost it can be expected that the price will drop. 
Those indicators of risks should be imposed and measured carefully, since it highly correlates with the overall economic, financial and residential market in a certain situation. We provide a simple model explaining the source of investor behavior, the determinants and the impact on residential project as shown in figure 2 .

\section{DISCUSSION}

As described in the second chapter of this paper, there are two main categories of investor's economic behavior to be considered as risk sources : (1). Rational behavior and (2). Psychological behavior. Both behavioral risks come from many different sources as determinants. react in a combination of rational and irrational behavior, which we call behavioral finance in their decision-making process when the overall situation becomes unpredictable, the market mechanism information is not sufficient for consideration.

Those instability in housing might lead to property booming which in many circumstances will be followed by bust. This is what the academics previously define as bubble formation phenomenon. While booming of price and sales volume of property will be beneficial and therefore become a very good opportunity, the bust/dramatic decline in price and volume of transaction will be a disastrous economic condition for the investors as well as developers and a very high risk for the project

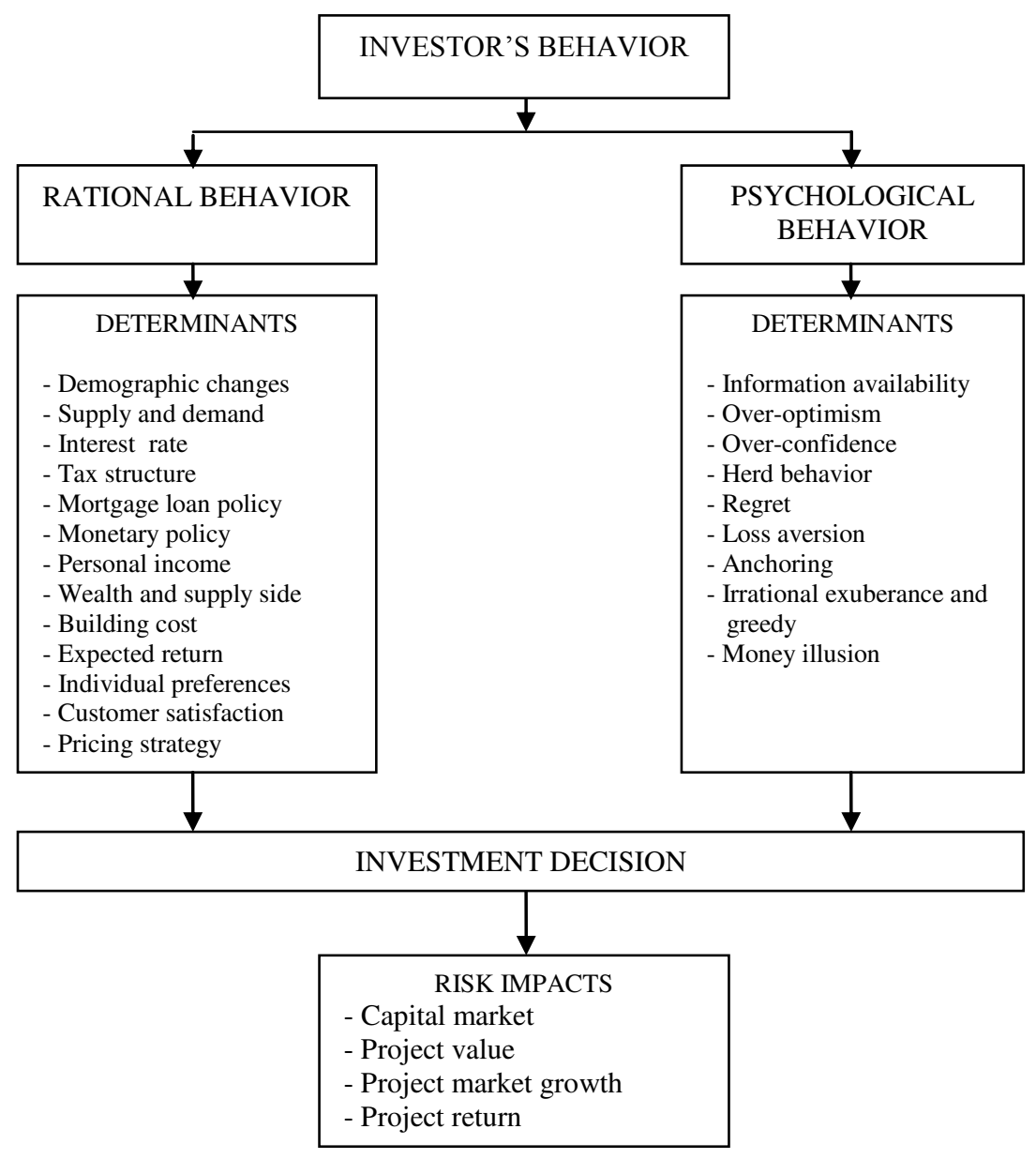

Figure 2. Map of the Investor Behavior Risk Sources Affecting Project Success [38].

We adopted a simple model explaining the source of investor behavior, the determinants and the impact on residential project is shown in figure 2[38].

When the political, monetary, financial circumstances are within normal condition, the market will be stable and the investors tend to think and act rationally in the decision making in residential investment. They will consider the basic economic fundamental such as preferences in the technical attributes of the product, and economic fundamentals i.e. pricing, mortgage policy and interest rate, expected return, etc. In turn, the residential project risk, particularly in economic aspect will be in a considerable stability and control. However, they tend to goals and for macroeconomics in general. For the residential project, that will directly affect on the market capitalization rate, value of the project and the sales growth rate. The degree of the riskiness might be within aggresive range. The events of the recent housing market crisis during 2009-2014 [39] in Indonesia demonstrate the enormous economic and financial costs associated with asset price bubbles and crashes.

There are many findings since Adam Smith developed a comprehensive and unusual version of moral sentimentalism in his Theory of Moral Sentiments in 1759 and later extended his theory proposed in his book Wealth of Nations published in 1776. The results of those studies 
vary in many aspects and assumption bases. We present later in this chapter a map of risk assessment criteria to show the economic risk and its important determinants concluded from some previous studies with the respective references. In order to obtain some explanation of housing bubbles as the most dangerous risk in residential project, we present some studies which research many different circumstances of risk, investor behavior, method of measurement, bubble and its indicators and residential project volatility.

A simple intuitive explanation of the mechanism behind bubble formation has been suggested by Shiller [27]: "If asset prices start to rise strongly, the success of some investors attracts public attention that fuels the spread of the enthusiasm for the market. New (often, less sophisticated) investors enter the market and bid up prices. This "irrational exuberance" heightens expectations of further price increases, as investors extrapolate recent price action far into the future. Themarket's meteoric rise is typically justied in the popular culture by some supercially plausible "new era" theory that validates the abandonment of traditional valuation metrics. But the bubble carries the seeds of its own destruction; if prices begin to sag, pessimism can take hold, causing some investors to exit the market. Downward price motion begets expectations of further downward motion, and so on, until the bottom is finally reached" [40].

A research by Hillebrand et.al [41] suggest that in the absence of a financial sector the only intergenerational transfer of commodities in our model is from the young to the old through the housing market. Consequently, housing values are bounded by young consumer incomes. Introducing a financial sector adds an additional channel of intergenerational trade in the form of a credit market, which mediates a commodity transfer from the old to the young. Regime switches occur due to small but persistent income changes giving rise to boom-bust cycles in housing prices. Price deviations from fundamentals are caused by leveraged borrowing, and turn out to be fully welfare-neutral. It is reasonable to assume that bubble formation in asset prices has its root in some basic aspects of the human social psychology, which may manifest itself as soon as some necessary conditions (such as the existence of basic liquid markets) are satisfied. Moreover, it is likely that bubble formation and collapse phenomena appear in areas of social dynamics beyond the asset price formation. Rahadi et al. [42] argue that external factor which cannot be controlled by either customer and real estate developer such as speculative behavior in the investment can heavily influence the price and value of housing product. Customers hoping to obtain quick gain from a real estate product can purchase it in bulk. Here, the process of supply and demand function kicked in and making price of the product increase uncontrollably. The same thing can be done by real estate developer. If the product is premium, real estate developer can sell the product in several phases. Real estate developer will sell the product like auction. Highest bidder will get the product. However, if the real estate developer conduct this action too aggressively, the strategy can backfire and hurt their reputation and brand. This action in the long-term can hurt the company's value and growth.

In his paper, Tomura [43] show that over-optimism of mortgage borrowers can cause boom-bust cycles, if mortgage borrowers are credit-constrained and savers who supply mortgage loans to mortgage borrowers do not share the over-optimism. Also, in the presence of price stickiness, the model generates a low policy interest rate during a housing boom as an endogenous reaction to a low inflation rate, given a Taylor rule. These results are consistent with the stylized features of housing- market boom-bust cycles observed in developed countries. The model focuses on over-optimism of future technological progress as the source of business fluctuations. To replicate more detailed observations than the stylized features of housing-market boom-bust cycles, it would be necessary to disentangle fundamental shocks from the effect of over-optimism in data and analyze the effect of fundamental shocks.

Bubbles require market participants to have access to funds to finance their inordinate asset purchases. As housing prices escalate, concerns arise that a lack of fundamentals was behind the high price increases, but a rapid increase in prices doesn't necessarily imply a bubble. The economic models based on these theories have shown striking inconsistencies between theory and evidence. Often, the simplest model with the unrealistic assumptions that market participants based future price performance on past price performance yields sharp insight into how a market or an economy works during a bubble. Interestingly, there's always a reason that what looks like a bubble is not really a bubble. Unfortunately, asset price bubbles and crashes in stocks and housing are here to stay, as human nature appears to play an important role in the shaping of speculative bubbles [3]. Glaeser [34] has argued that real estate experiences impressive booms and busts, which can reasonably be referred to as bubbles. Generally prices move too much to be fully explained by changes in either rents or observable fundamentals. Housing prices display substantial momentum at high frequencies, and they mean revert at lower frequencies. These general features were greatly exacerbated during the boom and bust of the 2000 to 2012 period [39]. The events of the recent housing bust demonstrate the enormous economic and financial costs associated with asset price bubbles and crashes and caused slowdown of residential project market which eventually made the projects fail to obatin their goals.

We summarize some of the critical economic risk factors identified from previous studies for residential project as presented in Table 3.

\section{CONCLUSION}

Residential development is a dynamic process involving almost all disciplines where each stage encounters various risks allocating between stakeholders as agents who have a high level of engagement, therefore they become one of the key success factor. This paper discussed previous literatures to examine the role and the impacts of investor behavior related risks in the residential project. In a relatively normal situation, investor will consider market and fundamental determinants, so the project team/ 
Table 3.

Critical Economic Risk Factors

\begin{tabular}{|c|c|c|c|c|c|c|c|c|c|c|c|}
\hline \multirow[b]{2}{*}{$\begin{array}{l}\text { Investor } \\
\text { Behavior }\end{array}$} & \multirow[b]{2}{*}{$\begin{array}{c}\text { Critical Risk } \\
\text { Factor }\end{array}$} & \multicolumn{10}{|c|}{ Authors } \\
\hline & & $\begin{array}{c}\text { E.Gran } \\
\text { ziera et } \\
\text { al. } \\
\text { (9) }\end{array}$ & $\begin{array}{l}\text { R.A.Ra } \\
\text { hadi et } \\
\text { al. } \\
(42)\end{array}$ & $\begin{array}{l}\text { S. } \\
\text { Amin } \\
\text { et al. } \\
(10)\end{array}$ & $\begin{array}{c}\text { A. } \\
\text { Grad } \\
\text { inaru } \\
(19)\end{array}$ & $\begin{array}{l}\text { D. Salz- } \\
\text { Man et } \\
\text { al. } \\
(8)\end{array}$ & $\begin{array}{c}\text { L.M. } \\
\text { Khode- } \\
\text { ir et al. } \\
\quad(44)\end{array}$ & $\begin{array}{l}\text { T.S. al } \\
\text { Nahdi } \\
\text { et al. } \\
(45)\end{array}$ & $\begin{array}{c}\text { H.To- } \\
\text { mura } \\
(43)\end{array}$ & $\begin{array}{c}\text { C. } \\
\text { Bering } \\
\text { er et al. } \\
\text { (4) }\end{array}$ & $\begin{array}{l}\text { A. } \\
\text { Filip } \\
\text { et al. } \\
(26)\end{array}$ \\
\hline \multirow{15}{*}{$\begin{array}{l}\text { Rational } \\
\text { Behavior }\end{array}$} & Investor preference & & $\mathrm{v}$ & & & & & $\mathrm{v}$ & & & \\
\hline & Tax regulation & & & & & $\mathrm{v}$ & $\mathrm{v}$ & & & & \\
\hline & Pricing & & & & & $\mathrm{v}$ & & & & & \\
\hline & Interest rate & & & $\mathrm{V}$ & & $\mathrm{v}$ & $\mathrm{v}$ & & & & \\
\hline & Discount factor & $\mathrm{V}$ & & & & & $\mathrm{v}$ & & & & \\
\hline & Currency fluctuation & & & & & & $\mathrm{v}$ & & & & \\
\hline & Market liquidity & & & & & $\mathrm{V}$ & & & & & \\
\hline & Inflation rate & & & & & & & & $\mathrm{v}$ & & \\
\hline & Housing stock & & & & & $\mathrm{v}$ & & & & & \\
\hline & Product attribute & & $\mathrm{v}$ & $\mathrm{V}$ & & & & & & & \\
\hline & Mortgage loan policy & & & $\mathrm{V}$ & & & & & $\mathrm{v}$ & & \\
\hline & Income/ wealth & $\mathrm{V}$ & & & & $\mathrm{V}$ & & $\mathrm{V}$ & & & \\
\hline & Expected return & & $\mathrm{v}$ & $\mathrm{v}$ & & & & & & & \\
\hline & Price-rent ratio & $\mathrm{V}$ & & & $\mathrm{V}$ & & & & & & \\
\hline & Satisfaction & & $\mathrm{v}$ & & & & & & & & \\
\hline \multirow{11}{*}{$\begin{array}{l}\text { Psycholo- } \\
\text { gical } \\
\text { Behavior }\end{array}$} & Irrational exuberance & & & $\mathrm{V}$ & $\mathrm{v}$ & $\mathrm{v}$ & & & & & \\
\hline & Speculative behavior & & $\mathrm{v}$ & $\mathrm{v}$ & & & & $\mathrm{v}$ & & & \\
\hline & Heuristic & & & & $\mathrm{V}$ & $\mathrm{V}$ & & & & & \\
\hline & Imperfect information & & & & $\mathrm{V}$ & $\mathrm{v}$ & & & & & $\mathrm{V}$ \\
\hline & Herd behavior & & & & & $\mathrm{v}$ & & & & & $\mathrm{v}$ \\
\hline & Loss aversion & $\mathrm{V}$ & & & $\mathrm{V}$ & $\mathrm{v}$ & & & $\mathrm{v}$ & & \\
\hline & Overconfidence & & & $\mathrm{v}$ & & $\mathrm{v}$ & & & $\mathrm{v}$ & & \\
\hline & Overoptimism & & & $\mathrm{v}$ & $\mathrm{v}$ & $\mathrm{v}$ & & & & & \\
\hline & Expect excessive gain & & & & $\mathrm{V}$ & $\mathrm{V}$ & & & & & \\
\hline & Anchoring & & & & & $\mathrm{V}$ & & & & & \\
\hline & Market turbulence & & & & & & & & & $\mathrm{V}$ & \\
\hline
\end{tabular}

developer can arrange strategies and manage the risks to achieve their goals based on general rules, but in times of economic and/or financial crisis the decision to invest at a certain period in time and the ways investors evaluate, assess and perceive risks is pretty much affected by psychological behavior rather than just relies on rational determinants. Household behaviors in boom and bust cycle, known as bubble phenomenon, are motivated by cognitive limitation and psychological bias. In the boom times, households' extrapolation bias and groupthink lead to chasing and extending asset bubbles. Increasing use of debt spurs the economy and eventually overburdens households. In burst times, the biases and fear lead to selling previously popular assets at low prices. Households generally respond to bust times by spending less, repaying debt and saving more, which drags on an already slow economy. Eventually the market volatility will affect the market growth, value appreciation and capital market for the firms.

We conclude that household psychological behavior plays an important role in housing project, so that it could become a very potential risk. In this regard, behavioral finance is an alternative and beneficial approach in assessing residential project risk of residential projects. For future research we suggest to analyse the risks in the aspect of qualitative and quantitative aspect of investor behavior using behavioral finance perspective for specific segment of residential project particularly in major urban areas in Indonesia to obtain a comprehensive findings and alternatives in identifying and assessing residential risks.

$$
\text { VI. ACKNOWLEDGEMENT }
$$

We would like to express our gratitude to the Chair and the Committee of The RCCE 2017 and 3rd ICCER 2017 for the opportunity to participate in The Third International Conference on Civil Enginering Research.

\section{REFERENCES}

[1] PMI, "A Guide to the Project Management Body of Knowledge", 5th ed, Pennsylvania: Project Management Institute, Inc, 2013, pp. 417-420.

[2] A. Adair and N. Hutchison, " The reporting of risk in real estate appraisal property risk scoring", Journal of Property Investment \& Finance, vol. 23, 2005, pp.254-268, 2005.

[3] L. B. Torres," Housing Bubbles and economic fundamentals", Real Estate Center, Texas A\&M Univ., 2014. [6] A.A.E. Othman, "Incorporating value and risk management concepts in developing low cost housing projects", Emirates Journal for Engineering Research, vol.13, pp.45-47, 2008.

[4] C. Beringer, D. Jonas and A. Kock' " Behavior of internal stakeholders in project portfolio management and its impact on success", International Journal of Management, vol. 31, pp. 830-831, 2013.

[5] Z. Chen and S. Khumpaisal, "An analytic network process for risk assessment in commercial real estate development", Journal of Property Investment and Finance, vol. 27 (3), pp. 238-258, 2009.

[6] A.A.E.Othman, "Incorporating value and risk management concepts in developing low cost housing projects", Emirates Journal for Engineering Research, vol.13, pp.45-

\section{7, 2008}


[7] J. M. Quigley, “ Real estate and the Asian crises. Journal of Housing Economics, pp. 129-161, 2001.

[8] D. Salzman and R.C.J. Zwinkels, "Behavior real estate", presented at the Duisenberg school of finance-Timbergen Institute, London, UK, July 2013

[9] E. Granziera and S. Kozicki," Fundamentals and expectations", Journal of Economic Dynamics and control", vol. 60, pp. 152-153, 2015.

[10] S. Amin and S.S.Pirzada, " Theory of behavioral finance and its application to property market: A change in paradigm', Research Journal of Finance and Accounting, vol. 5, no.13, pp. 132-134, 2014

[11] J. Diaz, " The first decade of behavioral research in the discipline of property', Journal of Property Investment\&Finance, vol.17(4), pp.326-336, 1999.

[12] P. Gallimore, J.A.Hans and A.Gray," Decision making in small companies", Journal of Property Research, vol.19(2), pp. 602-612, 2000.

[13] R.A.Rahadi, S.K.Wiryono, D.P.Koesrindartono and I.B.Syamwil," Relationship between consumer preferences and value proposition", Procedia Social and Behavioral Sciences, vol. 50, pp. 865-874, 2012

[14] E.F. Fama, " Efficient capital market: A Review of theory and empirical work", The Journal of Finance, vo.25(2), pp. $383-417,1970$.

[15] A. Farlow, "Housing, consumption and the economy: Why do house prices become misaligned, and what are the consequences?, London, 2005.

[16] A.J. Jaffe and C.F. Sirmans, " Fundamentals of real estate investment', Englewood Cliffs, NJ, Prentice-Hall, 1995.

[17] N.J. Vriend," Rational behavior and economic theory", Journal of economic behavior and organization, vol.29, pp. 263-285, 1996.

[18] R. Whittle, T. Davies and M. Gobey, " Behavioral economics and house prices: A literature review, Business and Management Horizon, vol.2 (2), pp. 17-23, 2014.

[19] A. Gradinaru," The contribution of behavioral economics in explaining the decision process", Procedia Economics and Finance, vol.16, pp.417-426, 2014

[20] J.W. Payne, J.R.Bettmen and E.J. Johnson, " Adaptive strategy selection in decision making", Journal of experimental psychology: Learning, Memory and Cognition, vol.14, pp. 534-552, 1988.

[21] N.Wilkinson and M.Klaes, " An introduction to behavioral economics", 2nd ed, Palgrave McMillan, NY, 2005.

[22] K.E. Case and R.J. Schiller," The efficiency of the market for single-family homes", The American Economic Review, vol 79(1), pp. 125-137, 1989.

[23] W. De Bondt," Real estate cycles and animal spirits”, In Pagliari, 1st (Ed), The Real Estate Portfolio Handbook, Richar Irwin, Chicago, USA, 1995.

[24] H.A. Simon, " Theories of decision-making in economics and behavioral science", The American Economic Review, vol 49(3), pp. 253-283, 1955.

[25] A. Farlow, "The UK housing market: Bubbles and buyers', presented at The Credit Suisse First Boston Housing Market Conference, 2005.

[26] A. Filip, M. Pochea and A. Peece, " The Herding behavior of investor in the CEE stock market", Procedia Economics and Finance, vol.32, pp. 307-315, 2015.

[27] R.J. Shiller," Irrational Exuberance", 2ed, Princeton University Press, USA, 2005.

[28] A. Morone and E. Samanidou," A simple note on herding behavior", Journal of Evolutionary Economics, vol. 18(5), pp. 639-646, 2008

[29] T. Lux," Herd behavior, bubbles and crashes", The Economic Journal, vol 105 (431), pp. 881-896, 1995.

[30] S. Bikchandani and S. Sharma," Herd behavior in financial markets", IMF Papers, vol 47,, 279-310, 2001.

[31] M.A. De Weaver and R. Shannon," Waning vigilance and the disposition effect: Evidence from Thailand on individual investor decision making", Journal of Socioeconomics, vol. 39(1), pp. 18-23, 2010.

[32] D. Kahneman and A. Tversky," Prospect theory: An analysis of decision under risk", Econometrica, vol 47(2), pp. 263-292, 1979.

[33] Backman, Lars, C von Hofsten," Psychology at the turn of the millenium: Cognitive, biological and health perspectives", 2002.

[34] Z. Chen and S. Khumpaisal, " Risk assessment in real estate development”, JARS, vol. 7 (1), pp.108-109, 2010.

[35] C. A. Clausen, M. Jonsson, \& B. Lagerwall,"En makroekonomisk analyd av bostadspriserna i Sverige. Stockholm: Sveriges riksbank, 2011.

[36] E.L. Glaeser," A nation og gamblers: real estate speculation and American history", American Economic Review, vol 103(3), pp. 63-83, 2013.

[37] D. M. Geltner, N.G. Miller., J. Clayton \& P Eichholtz,. “ Commercial real estate Analyses and investments", Mason, OH: Thomson Higher Education, 2007.

[38] S.M. Renuka, C. Umarani and S. Kamal," A review on critical risk factors in the life cycle of construction projects", Journal of Civil Engineering Research, vol 4 (2A), pp. 31-36, 2014

[39] Statistic Department of Bank Indonesia,"Residential Property Survey for Primary House”, pp.1, 2015.

[40] A. Kiselev and L Ryzhik, "A simple model for asset price bubble formation and collapse", University of Wisconsin, Madison, WI,1991.

[41] M. Hillebrand and T. Kikuchi, "A mechanism for booms and busts in housing prices", Journal of Economic Dynamics \& Control, vol. 51, pp. 204-2017, 2015.

[42] R.A.Rahadi, S.K.Wiryono and D.P.Koesrindartono, “ Attributes influencing housing product value and price in Jakarta metropolitan region", Procedia Social and Behavioral Sciences, vol. 101, pp. 368-378, 2013.

[43] H. Tomura, "Heterogeneous beliefs and housing-market boom-bust cycles", Journal of Economic Dynamics \& Control, vol. 37,pp. 735-755, 2013.

[44] L.M. Khodeir and A.H.M. Mohammed, " Identifying the latest risk probabilities affecting construction projects in Egypt according to political and economic variables"', HBRC Journal, vol. 11, pp.129-135.

[45] T. Salah Al Nahdi and O.H. Ghazzawi," Behavioral factors affecting real estate purchasing", International Journal of Business and Social Science, vol. 6 (8), pp. 147-150, 2015. 